Egyptian Journal of Aquatic Biology \& Fisheries

Zoology Department, Faculty of Science,

Ain Shams University, Cairo, Egypt.

ISSN $1110-6131$

Vol. 25(2): 913 - 933 (2021)

www.ejabf.journals.ekb.eg

\title{
Evaluation of molluscicidal, miracicidal and cercaricidal activities of crude aqueous extracts of Origanum majorana, Ziziphus spina-christi and Salvia fruticosa on Schistosoma mansoni and Schistosoma haematobium
}

\author{
Mohamed F. Abou El-Nour \\ Department of Zoology, Faculty of Science, Al-Azhar University, Nasr City 11884, Cairo, Egypt \\ fathallahaziz@yahoo.com
}

\begin{abstract}
ARTICLE INFO
Article History:

Received: Jan. 4, 2021

Accepted: April 19, 2021

Online: April 30, 2021

Keywords:

Molluscicide;

Plant extracts;

Origanum majorana;

Ziziphus spina-christi;

Salvia fruticosa;

Schistosoma mansoni;

S. haematobium

\section{ABSTRACT}

Schistosomiasis has been classified as a category II disease after malaria in importance as a targeted tropical disease. Praziquantel (PZQ) which is the chemotherapeutic agent of choice against adult worms, already faces drawback of drug resistance in some Schistosoma isolates. Therefore, searching for new alternative drugs has been the intention of many researchers. In the current study, the effect of different doses 6.25, 12.5, 25. 50. 100 and $200 \mathrm{mg} / \mathrm{ml}$ of Origanum majorana, Ziziphus spina-christi, and Salvia fruticosa extracts on the snails Bulinus truncatus of the S. haematobium and Biomphalaria alexandrina of the Schistosoma mansoni as well as on the free-living stages miracidia, in addition, the cercariae for both Egyptian species of schistosomes were studied. The results declared that Origanum majorana, Ziziphus spina-christi showed efficacy against snails (molluscicidal), miracidia (miracicidal), and cercariae (cercaricidal) for both Egyptian species of schistosomes in the in vitro, while Salvia fruticosa was less effective than the previous ones.
\end{abstract}

\section{INTRODUCTION}

Infectious diseases are the infection of a living organism with one of these five organisms: viruses, bacteria, fungi, protozoa, and helminthes. Worldwide, annually due to infectious diseases more than 13 million deaths occur, the largest proportion of which are in the developing world (Sachs, 2001). About 218 million people suffer from schistosomiasis worldwide, it's a weaken and sometimes fatal disease, nearly, on the African continent no country is safe from this infection, currently, $90 \%$ of the cases present in Africa alone especially in sub-Saharan, and two species only out of five species (Schistosoma mansoni and Schistosoma haematobium) infect human causing 80\% of schistosomiasis in Africa (Anyan, et al., 2019; Ndassi et al., 2019), therefore according to the WHO Special Program for Research and Preparing in Tropical Diseases, schistosomiasis has been classified as a category II disease after malaria in importance as a targeted tropical disease. Possible results of schistosomiasis infection in children include nutritional deficiency, dysuria, hematuria, watery hypertrophy, dwarfism, and urinary bladder lesions (Saathoff et al., 2004), while if the infection persists for a long time to adulthood, it can cause cancer, increase in exposure to HIV and infertility (Kjetland et al., 2006; King and Dangerfield-Cha, 2008). 
Blood flukes of the genus Schistosoma are a parasite that causes an acute or chronic disease called schistosomiasis or snail fever (Obare et al., 2016). It is widespread in poor communities with inaccessible safe drinking water and adequate sanitation services in the tropical and subtropical regions (WHO, 2016). Schistosomiasis in Egypt is responsible for about 35\% of chronic liver diseases in children, as well as $70 \%$ of liver diseases in adults, therefore it is classified as an endemic disease (Abd El-Ghany et al., 2018). Also in Egypt, most people do agricultural work on irrigation farms, recreational activities, and household chores. For these reasons, they are always exposed to the water that contains the free-swimming larvae infective stage (cercariae), which comes out of the freshwater snail (Guo et al., 2016). In Egypt, Biomphalaria alexandrina freshwater snail is the intermediate host of Schistosoma mansoni (Ibrahim and Abdalla, 2017), also, Bulinus truncatus snail which is widely distributed all over Egypt is the intermediate host of Schistosoma haematobium (Youssef, 2010; Bakry et al., 2004; 2015). There are four distinct points by which we can stop transmission of schistosomiasis: first is preventing human fecal materials (sanitation) from reaching freshwater, second is controlling broad intermediate host snails to prevent the interaction of larval stages of schistosomes (miracidia, cercariae), third is preventing human exposure to the infective stage free-swimming cercariae (reducing contact with water), and fourth is the chemotherapy of PZQ on the parasite that lives inside the human host.

At present, there is no vaccine available, and Praziquantel (PZQ) which is the chemotherapeutic agent of choice against adult worms, already faces drawback of drug resistance in some Schistosoma isolates (WHO, 2011). Reducing the incidence and spread of schistosomiasis by using molluscicides to control snails has been led to a significant impact on a devastating decrease of the fresh-water snails' population which are the intermediate host. Environmental and economic considerations are increasing for the use of molluscicides that are biodegradable, selectively active, readily available in the affected areas and inexpensive. Niclosamide is a pesticide used as a positive control and consists of 5 chloro-N- ( 2 chloro-4nitrophenyl)-2-hydroxy-benzamide (Guo et al., 2016). Nevertheless, any chemical compound such as niclosamide does have some drawbacks that involve a risk of toxicity for aquatic plants, fish, birds, domestic animals, and humans, lower solubility, and expensive cost. Also, to achieve snail control niclosamide should be used continuously over a longer time period, and this can lead to drug resistance (Kenawy and Rizk, 2004; Guo et al., 2008; Li et al., 2013; Guo et al., 2016). There are also other compounds that have a fatal effect on adult snails and embryos, such as copper, but they are not used regularly in common practices because they are absorbed by soil and organic materials (Ribeiro et al., 2009; Martins et al., 2014). Consequently, it's imperative to develop alternative substances for their control of mollusca, miracidia and cercariae, as they are effective, prove safe for aquatic organisms, cheap, easily available, and simply applicable agents.

The utilization of some medical plants with molluscicidal properties seems to be an inexpensive and simple alternative to chemical molluscicides (Perrett and Whitfield, 1996). To reveal the activity of some plants against snails, more than 1000 plant species were examined (ElBolkiny et al., 1997). In Egypt, with great interest, some local plants have been examined for molluscicidal activity (Sakran, 2004; Sakran and Bakry, 2005; El-Sayed et al., 2006; Bakry and Hamdi, 2007; Bakry, 2009; Bakry et al., 2016). Several plants have already been identified as useful to control the intermediate hosts of trematodes such as Solanum xanthocarpum, Phytolacca dodecandra (Endod), Thuja orientalis, Annona squamosa, Adenium arabicum, and Calotropis procera (Al-Sarar et al., 2012). Phytolacca dodecandra in Ethiopia was the most 
active plant against snail intermediate hosts of schistosomes and its aquatic larvae (molluscicidal, cercaricidal, and miracicidal activities) (Lemma, 1970). However, experiments have been proven toxic to non-target organisms such as fish (Lemma, 1970). Matos et al. (2020) found a fatal effect of curcumin on snails (Biomphalaria glabrata) and cercariae in Schistosoma mansoni.

Origanum majorana is also known as sweet marjoram. It belongs to the family of Lamiaceae (syn. Majorana hortensis Moench). Origanum herb, reported the presence of a large number of constituents in different parts of the plant, especially terpenoids (Raina and Negi, 2012), phenols (Nakatani, 2000) and flavonoids as major constituents due to its aromatic nature and other chemical constituents like steroids (Leung and Foster, 1996), fatty acids and vitamins (Janicsák et al. 1999) as a minor component. Origanum majorana leaves are also a vital medicinal herb in modern medicine primarily for extraction of Origanum, one of its main phytochemicals. The extracted of Origanum majorana have been used effectively against protozoans e.g., Pentatrichomonas hominis (Kozlowska et al., 2010); anti-bacterial (Mohamed et al., 2011); anti-fungal (Sharma et al., 2011); insecticidal (Sharma et al., 2011); anticonvulsant (Deshmane et al., 2007); anti-diabetic (Martha and Gutierrez, 2012); anti-gout (Vasudeva et al., 2014); anti-mutagenic activity (Al-Harbi, 2011); anti-ulcer (Vagi et al., 2005).

Ziziphus spina-christi (L.) belongs to the Rhamnaceae family. These trees produce small orange-yellow fruits and are also evergreen. Its common name in the countries of the Middle East is Nabka or Sidr. This plant is native to western and southern Asia and north and tropical Africa. In Egypt, wild plants are found mainly in the Sinai (Michel et al. 2011). Ziziphus spina-christi contains many essential oils for example, methyl stearate, methyl palmitate, and geranyl acetate, quercetin derivative from the flavonoids groups and triterpenoid sapogenins from the saponins groups and betulinic acid, phytosterols such as beta-sitosterol, alkaloids such as cyclopeptide, spinanine-A, tannins, phytosterols, triterpenoid sapogenins, and saponins (Kadioglu et al. 2016). Ziziphus spina-christi is used in traditional folk medicine for antibacterial, antiviral, hypoglycemic, diuretic, anticathartic, tonic activities, hepatoprotector and immunostimulant (Amin and Mahmoud-Ghoneim 2009; Michel et al. 2011; Mubaraki et al. 2017).

Salvia fruticosa (common name is Greek sage) belongs to the family Lamiaceae), it is an herb that is completely covered with hair and with the increased growth of leaves of different sizes that gives the plant an intense and silver appearance. It is a perennial plant or sub-shrub native to the eastern Mediterranean, including North Africa, the Canary Islands and southern Italy. It is especially abundant in Palestine (Koutsoulas et al., 2019). Numerous previous studies have identified many biologically active compounds and search their pharmacological properties, many of these species are also used in traditional medicine. These studies revealed the antiinflammatory, antioxidant, anti-diabetic, as well as anti-tumor activities of isolates, and plant extracts. These effects are mainly attributed to terpenes, coumarins, flavonoids, plant phenols and carotenoids such as carnosic acid (California, terpenes) and rosmarinic acid (phenol) (DuletićLaušević et al., 2018 and Fraihat et al., 2018).

The present work was planned to study the effect of lethal concentrations of the extracts of Origanum majorana, Ziziphus spina-christi and Salvia fruticosa on Bulinus truncatus with $S$. haematobium and Biomphalaria alexandrina with Schistosoma mansoni (molluscicidal), as well as on the free-living stages miracidia (miracicidal), in addition cercariae (cercaricidal) for both Egyptian schistosomes species. 


\section{MATERIALS AND METHODS}

\section{Plant materials}

Origanum majorana, Ziziphus spina-christi and Salvia fruticosa leaves were obtained and identified in the Horticulture department, Faculty of Agriculture, Ain Shams University. The part of the collected plant was cleaned, washed, and dried in the shade; and was not exposed to sunlight for avoid the losing the active ingredients.

\section{Aqueous extract preparation}

By electric grinder, the dried materials were ground into a fine powder. A quantity of crushed leaves weighing $200 \mathrm{~g}$ was dissolved with two liters of distilled water at a ratio $(1: 10 \mathrm{w} / \mathrm{t})$ by the method of cool extraction and evaporated of the extract in vacuo. The extracts were concentrated in vacuo by using a rotary evaporator at $40^{\circ} \mathrm{C}$. Finally, the extracts were placed in porcelain dishes in a temperature-controlled oven to remove the remaining water in the extracts to give a residue of $8.5 \mathrm{~g}$. The residues were stored at $4^{\circ} \mathrm{C}$ for further use (Ekpo and Etim, 2009).

\section{Toxicological study}

The maximum non-toxic concentration (MNTC) (the maximum concentration without toxic effect and expressed in $\mu 1 / \mathrm{ml}$ ) of the plant extract on Vero cells had been carried out by serial dilutions of $(10-300 \mu \mathrm{l} / \mathrm{ml})$. Briefly, $2 \times 10^{5}$ cells $/ \mathrm{ml}$ of Vero cells were treated with the serial dilutions of the extract in microtiter plates and had been incubated at $37^{\circ} \mathrm{C}$ in a carbon dioxide (5\% humidity) for 72 hours. Furthermore, the microscopic plates were examined in order to determine the toxic concentration of the extract through its ability to induce cell death. Cytotoxicity of the extract concentration at 50\% was not exceeded to maintain the cell viability and their ability to cleave the tetrazolium salt MTT [3-(4,5-dimethylthiazol-2-yl)-2,5-diphenyl tetrazolium bromide (Sigma, Chem, St. Louis, MO), producing formazan blue product (Mosmann, 1983). Briefly, supernatants were removed from the wells, and $25 \mu 1$ of an MTT (Sigma, St. Louis, MO) solution ( $2 \mathrm{mg} / \mathrm{ml}$ in PBS) had been added to each well, and the plates were incubated at $37^{\circ} \mathrm{C}$ for 90 minutes. Then, DMSO $(25 \mu \mathrm{l})$ was added to each well to get rid of crystallized formazan. The plates were kept for $15 \mathrm{~min}$ on a shaker to be ready for the determination of the optical density at $492 \mathrm{~nm}$ (OD492). The MNTC value is the extract dilution which maintains normal cells morphologically and density in comparison with the untreated control cells with at least $95 \%$ of the optical density.

\section{Identification of most potent plant extract}

Identification of antischistosomal activity of three plants: Origanum majorana, Ziziphus spina-christi and Salvia fruticosa assessed at the Regional Center for Mycology and Biotechnology (RCMB) at Al-Azhar University Egypt by extraction method, and absorbance of oil solutions in methanol measured with UV-240 spectrophotometer (Schimmadzu-Corporation, Kyoto, Japan). The preparation of the extract was done by maceration method. Maceration was done using the appropriate solvent with several times shaking or stirring at room temperature (Rader et al., 2007).

\section{(GC-MS) Gas Chromatography-Mass Spectrometry analysis}

Using a DELSI $121 \mathrm{C}$ device equipped with a flame ionization detector and silica column contained a CP WAX $51(25 \mathrm{~m} \times 0.25 \mathrm{~mm}$ i.d., $0.25 \mu \mathrm{m}$ film thicknesses $)$, analytical gas chromatography (GC) was performed to identify the main components that present in the extracts. The temperature was maintained at $50{ }^{\circ} \mathrm{C}$ for five minutes and programmed to reach 220 
${ }^{\circ} \mathrm{C}$ at $3{ }^{\circ} \mathrm{C}$ per minute. ACPWAX 51merged silica WCOT column $(60 \mathrm{~m} \times 0.25 \mathrm{~mm}$ i.d., 0.25 $\mu \mathrm{m}) \mathrm{GC} / \mathrm{MS}$ with carrier gas helium is used. For GC/MS, a CPWAX 52 merged silica CB column $(50 \mathrm{~m} \times 0.3 \mathrm{~mm} ; 0.25 \mu \mathrm{m}$ film thickness $)$ was used with HP mass spectrometer and couple to helium as a carrier gas: the energy of ionization $70 \mathrm{~V}$. Temperature was Programmed to rise at a rate of $3{ }^{\circ} \mathrm{C} / \mathrm{min}$ to reach from $50^{\circ} \mathrm{C}$ to $240^{\circ} \mathrm{C}$. At a temperature of $240{ }^{\circ} \mathrm{C}$ samples were injected into an injector. By comparing Kovats indices (KI) linear with the components were identified, mass spectra and their time of retention (RT) with those acquired from the original samples and/or the MS library.

\section{Experimental design}

\section{Snails}

Biomphalaria alexandrina freshwater snails are the intermediate host of Schistosoma mansoni, and Bulinus truncatus freshwater snails are the intermediate host of Schistosoma haematobium, they were obtained from Medical Malacology Laboratory at Theodore Bilharz Research Institute (TBRI), Imbaba, Giza, Egypt, their sizes were ranging from 13 to $18 \mathrm{~mm}$ for Biomphalaria alexandrina and from 8 to $12 \mathrm{~mm}$ for Bulinus truncatus and, the snails were placed in plastic aquaria with a size of $9 \times 23 \times 16 \mathrm{~cm}$, ten snails per liter of water were placed in aquaria to avoid congestion between snails, with dechlorinated aerated tap water the aquaria were supplied, and covered with glass plate. The snails were feeding on dried lettuce leaves in the oven and were kept under ordinary room temperature $(25 \pm 2)$ and the water used to change for the snails in aquaria twice weekly.

\section{Molluscicidal activity}

According to the WHO guidelines, a molluscicidal evaluation of medicinal plant extracts were performed (WHO, 2019). Four groups (equal to the number of concentrations), each group consists of ten uninfected snails (for each concentration) placed in glass beakers at room temperature.

Snails were exposed to concentrations of $6.25,12.5,25.50 .100$ and $200 \mathrm{mg} / \mathrm{ml}$ for $24 \mathrm{hr}$. at $26{ }^{\circ} \mathrm{C}$. After the 24 -hour period, the snails were removed from the solution containing the extracts and washed thoroughly with dechlorinated tap water, the snails were transferred to containers with deionized and dechlorinated water for another 24 hrs. of recovery. Dead snails were counted and confirmed by eliciting typical pull movements of the foot by using a wooden blunt nail and the absence of a heartbeat. This step was done in three replications. The negative control was dechlorinated water, in addition to the deionized water, in contrast, the positive control was water with niclosamide. The snails were not disturbed or fed during the exposure and recovery interval. $\mathrm{LC}_{50}$ and $\mathrm{LC}_{90}$ were calculated according to Leitchfield and Wilcoxon (1949).

\section{Hatching of miracidia from infected hamster}

Schistosoma mansoni and Schistosoma haematobium eggs were obtained from golden hamster (Mesocricetus auratus) with chronic infection maintained at the Schistosome Biological Supply Center (SBSC) at Theodor Bilharz Research Institute (TBRI), Embaba, Giza, Egypt. In a one-liter plastic container containing saline solution the hamster faeces was mixed. The mixture was passed through two sieves, the sieve size is $600 \mu \mathrm{m}$ and the second size is $250 \mu \mathrm{m}$ and the filter was collected in a metal plate. Then the collected filtrates were placed in a jar and left for 30 minutes in the dark. A clear supernatant was removed, a new saline was added and leave for three minutes, this step was repeated three times. Finally, the sediment was placed under artificial light for 30 minutes at a temperature from $20-25{ }^{\circ} \mathrm{C}$ until the exit of the miracidia. The later was used for miracicidal assay and snail's infection. 


\section{Infection of snails with miracidia}

Biomphalaria alexandrina snails were infected with Schistosoma mansoni and Bulinus truncatus snails were infected with Schistosoma haematobium. This was done by using a long glass pipette to pull five miracidia from a Petri dish containing hatched miracidia. In a 24 well culture plate the miracidia were dispatched into each well. Then, individually, the snails were transferred into these wells and left for 30 minutes to allow miracidia to penetrate the soft body of snails; the wells were covered with plates to prevent the snails from crawling out. The snails were moved to a place where the lighting was $12 \mathrm{hr}$ and darkness 12 hours for three weeks. In the fourth week, which is prepatent period of snails (before the infected snails pass five weeks), they were placed in the dark, to prevent trickle shedding cercariae, the container was covered with dark clothes.

\section{Miracicidal activity}

A series of concentrations $(6.25,12.5,25.50 .100$, and $200 \mathrm{mg} / \mathrm{ml})$ of aqueous extracts were prepared for the three tested plants. One $\mathrm{ml}$ of dechlorinated tap water that contains twentyfive miracidia mixed with one $\mathrm{ml}$ of double concentration (this means when testing the concentration of $200 \mathrm{mg} / \mathrm{ml}, 400 \mathrm{mg} / \mathrm{ml}$ is used actually because adding the same volume of water containing miracidia dilutes the concentration to half in each concentrations) in a $5 \mathrm{~cm}$ Petri dish. Three replications were done with the same preceding controls. The positive group was a $2 \mathrm{ml}$ of one gram per liter of niclosamide and the negative group was a $2 \mathrm{ml}$ of distilled water. Dead or immovable miracidia were recorded at intervals of 15, 30, 60, 90, 120 and 180 min because their movement indicates that the organism is alive (WHO, 2019).

\section{Shedding of cercariae}

Five weeks after the infection, the snails were transferred to beakers containing dechlorinated water. To release the cercariae, the beaker was moved to under a 100-watt lamp shaded with glass. The cercariae were collected in a beaker and mixed well.

\section{Cercaricidal activity}

A series of concentrations $(6.25,12.5,25.50 .100$ and $200 \mathrm{mg} / \mathrm{ml})$ of aqueous extracts were prepared for the three tested plants. One $\mathrm{ml}$ of dechlorinated tap water that contains twentyfive cercariae mixed with one $\mathrm{ml}$ of double concentration in a $5 \mathrm{~cm}$ Petri dish. Three replications were done with the same preceding controls. The positive group was $2 \mathrm{ml}$ of one gram per liter of niclosamide and the negative group was $2 \mathrm{ml}$ of distilled water. Dead or immovable cercariae were recorded at intervals of 15, 30, 60, 90, 120 and 180 minutes because their movement have been used to indicate that the organism is alive (WHO, 2019).

\section{Infection of hamster with Schistosoma cercariae}

At the start of bioassay (week 0), general anesthesia was administered to the hamster to produce a loss of consciousness and suppression of reflex activity and muscle relaxation. A ratio based on the volume of 3:1 Ketamine and Rompun and (Agar, Holland) was used to provide a combined effect of anesthesia. An aesthesia dose of $0.02 \mathrm{ml} / 30 \mathrm{~g}$ hamster body weight was injected intraperitoneally. The anesthetized hamsters were shaved on the stomach area and on a wooden rack they were arranged. A piece of cotton wool had been dipped in water for use in moisturizing the shaven area to allow easy penetration of cercariae. A $1 \mathrm{~cm}$ ring of metal was placed on the shaven area of each hamster, then, a suspension constituting approximately 250 live cercariae were dispensed in the metal ring using a micropipette and kept for a period of 30 minutes to allow cercariae to penetrate the hamster (Smithers and Terry, 1965). 


\section{$\mathbf{L C}_{50}$ Calculator}

Sublethal $\left(\mathrm{LC}_{50}\right)$ values for different NLE concentrations were calculated by AAT Bioquest ${ }^{\circledR}$ calculator (Bioquest Inc. 2018).

\section{RESULTS}

\section{Cytotoxicity}

The cytotoxicity assay of tested plant extracts (Origanum majorana, Ziziphus spinachristi, and Salvia fruticosa) indicated that at Maximum Non-Toxic Dose (MNTD) of each extract-treated Vero cells did not show any morphological differences in comparison with control, at the value of 250,350 , and $300 \mu \mathrm{l} / \mathrm{ml}$, respectively.

\section{Phytochemistry}

Origanum majorana (Sweet marjoram) is characterized by a strong, spicy and pleasant odor and flavor. The chemical compositions of the important oils acquired from O. majorana are recorded in Table (1) (Fig. 1).

Table (1): Identified compounds in aqueous extract of Origanum majorana

\begin{tabular}{|c|c|c|c|c|c|c|}
\hline No. & RT & M.wt & M. formula & Prediction & Area & Area \% \\
\hline 1 & 20.52 & 204 & $\mathrm{C}_{15} \mathrm{H}_{24}$ & Zingiberene & 54727666.55 & 0.36 \\
\hline 2 & 20.80 & 222 & $\mathrm{C}_{15} \mathrm{H}_{26} \mathrm{O}$ & Nerolidol & 79653206.07 & 0.52 \\
\hline 3 & 26.89 & 222 & $\mathrm{C}_{15} \mathrm{H}_{26} \mathrm{O}$ & Cubenol & 90321047.45 & 0.59 \\
\hline 4 & 26.89 & 222 & $\mathrm{C}_{15} \mathrm{H}_{26} \mathrm{O}$ & Eudesmenol & 118361109.56 & 0.78 \\
\hline 5 & 28.42 & 220 & $\mathrm{C}_{15} \mathrm{H}_{24} \mathrm{O}$ & Cedren & 176248647.53 & 1.16 \\
\hline 6 & 30.66 & 30.66 & $\mathrm{C}_{15} \mathrm{H}_{22} \mathrm{O}$ & Phenol & 98240348.64 & 0.65 \\
\hline 7 & 30.81 & 30.81 & $\mathrm{C}_{11} \mathrm{H}_{14} \mathrm{O}_{3}$ & Butanone & 163365217.48 & 1.08 \\
\hline 8 & 33.26 & 222 & $\mathrm{C}_{15} \mathrm{H}_{26} \mathrm{O}$ & Eudesmol & 106173887.45 & 0.70 \\
\hline 9 & 36.84 & 188 & $\mathrm{C}_{9} \mathrm{H}_{16} \mathrm{O}_{4}$ & Propanol & 164765320.50 & 1.08 \\
\hline 10 & 45.71 & 276 & $\mathrm{C}_{17} \mathrm{H}_{24} \mathrm{O}_{3}$ & Gingerol & 6205744296.17 & 40.86 \\
\hline 11 & 47.93 & 200 & $\mathrm{C}_{6} \mathrm{H}_{9} \mathrm{FN}_{60}$ & Capsaicin & 274275241.47 & 1.81 \\
\hline 12 & 48.83 & 292 & $\mathrm{C}_{21} \mathrm{H}_{4} \mathrm{O}$ & Nonivamide & 151523642.98 & 1.00 \\
\hline 13 & 60.25 & 412 & $\mathrm{C}_{29} \mathrm{H}_{48} \mathrm{O}$ & Stigmasterol & 92898328.92 & 0.61 \\
\hline 14 & 61.17 & 414 & $\mathrm{C}_{29} \mathrm{H}_{50} \mathrm{O}$ & á-Sitosterol & 351889991.52 & 2.32 \\
\hline
\end{tabular}




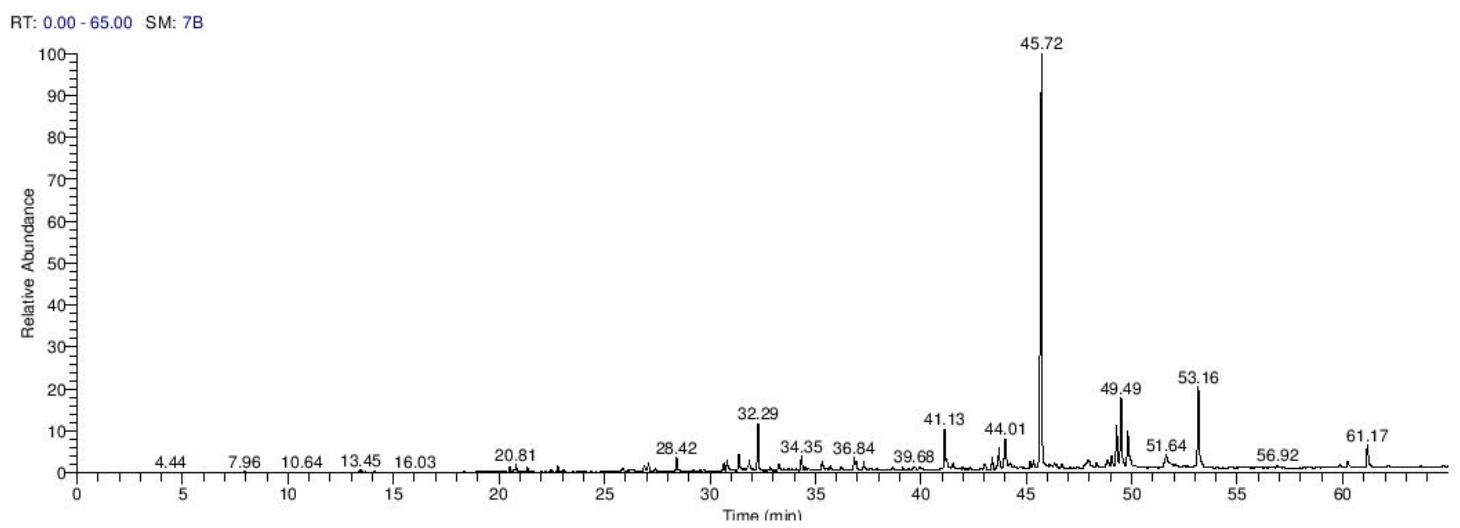

Fig. (1): GC-MS chromatogram of aqueous plant extract of Origanum majorana

On the other hand, the chemical compositions of the important oils acquired from Ziziphus spina-christi (L) are listed in Table (2) (Fig. 2).

Table (2): Identified compounds in aqueous extract of Ziziphus spina-christi (L.)

\begin{tabular}{|c|c|c|c|c|c|c|}
\hline No. & RT & M.wt & M. formula & Prediction & Area & Area \% \\
\hline 1 & 13.23 & 615 & C23H45N5O14 & D-Streptamine & 8421115.74 & 0.48 \\
\hline 2 & 17.73 & 592 & C16H48O8Si8 & Cyclooctasiloxane & 36726047.85 & 2.11 \\
\hline 3 & 19.82 & 110 & C6H6O2 & Hydrochinon & 54912618.86 & 3.15 \\
\hline 4 & 20.47 & 145 & C8H7N3 & Benzene & 70108424.28 & 4.02 \\
\hline 5 & 20.89 & 458 & C28H30N2O4 & Morphinan & 28332599.99 & 1.62 \\
\hline 6 & 24.58 & 220 & C15H24O & Tricycloundecan & 16114395.18 & 0.92 \\
\hline 7 & 24.58 & 220 & C15H24O, & Spathulenol & 16114395.18 & 0.92 \\
\hline 8 & 24.76 & 153 & C6H7N3O2 & Imidazole & 19324582.43 & 1.11 \\
\hline 9 & 26.32 & 190 & C13H18O & Megastigmatrienone & 17929010.41 & 1.01 \\
\hline 10 & 26.93 & 283 & C10H13N5O5 & Guanosine & 22821026.68 & 1.31 \\
\hline 11 & 32.76 & 279 & C10H17NO6S & Desulphosinigrin & 20218112.12 & 1.16 \\
\hline 12 & 41.28 & 519 & C30H53NO4Si & Glycine & 28017325.31 & 1.61 \\
\hline 13 & 46.99 & 286 & C20H30O & Phenanthrenemethanol, & 33473432.07 & 1.92 \\
\hline 14 & 53.07 & 439 & C31H21NS & Thienopyridine & 14058118.79 & 0.81 \\
\hline 15 & 61.17 & 414 & C29H50O & á-Sitosterol & 98265259.33 & 5.63 \\
\hline
\end{tabular}




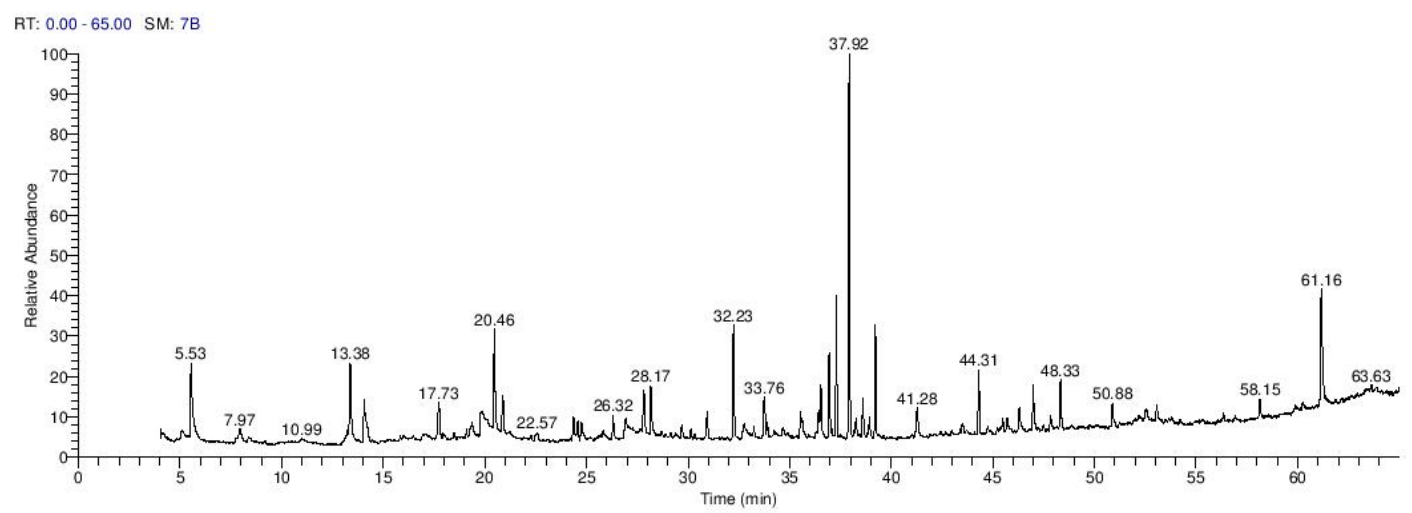

Fig. (2): GC-MS chromatogram of aqueous plant extract of Ziziphus spina-christi

The chemical compositions of the important oils acquired from Salvia fruticosa are listed in Table (3) (Fig. 3).

Table (3): Identified compounds in aqueous extract of Salvia fruticose

\begin{tabular}{|c|c|c|c|c|c|c|}
\hline No. & RT & M.wt & M. formula & Prediction & Area & Area \% \\
\hline 1 & 10.43 & 341 & C20H23NO4 & Quinolinol & 3053550.06 & 3.26 \\
\hline 2 & 14.16 & 576 & C18H52O7Si7 & Tetrasiloxane & 3831389.13 & 4.08 \\
\hline 3 & 20.88 & 428 & C27H44O2Si & Androstadienol & 2861964.11 & 3.05 \\
\hline 4 & 22.53 & 283 & C10H13N5O5 & Purinol & 1584222.84 & 1.69 \\
\hline 5 & 30.94 & 428 & C27H40O4 & Spirosten & 1522237.77 & 1.62 \\
\hline 6 & 32.36 & 256 & C16H32O2 & Tetradecanoic acid & 12521180.76 & 13.35 \\
\hline 7 & 35.11 & 195 & C11H17NO2 & Benzenemethanol & 4860449.32 & 5.18 \\
\hline 8 & 36.42 & 366 & C13H30N2O4SSi2 & Cystathionine & 1306854.22 & 1.39 \\
\hline 9 & 49.30 & 514 & C27H31BrO5 & Terphenyl & 2374908.89 & 2.53 \\
\hline
\end{tabular}

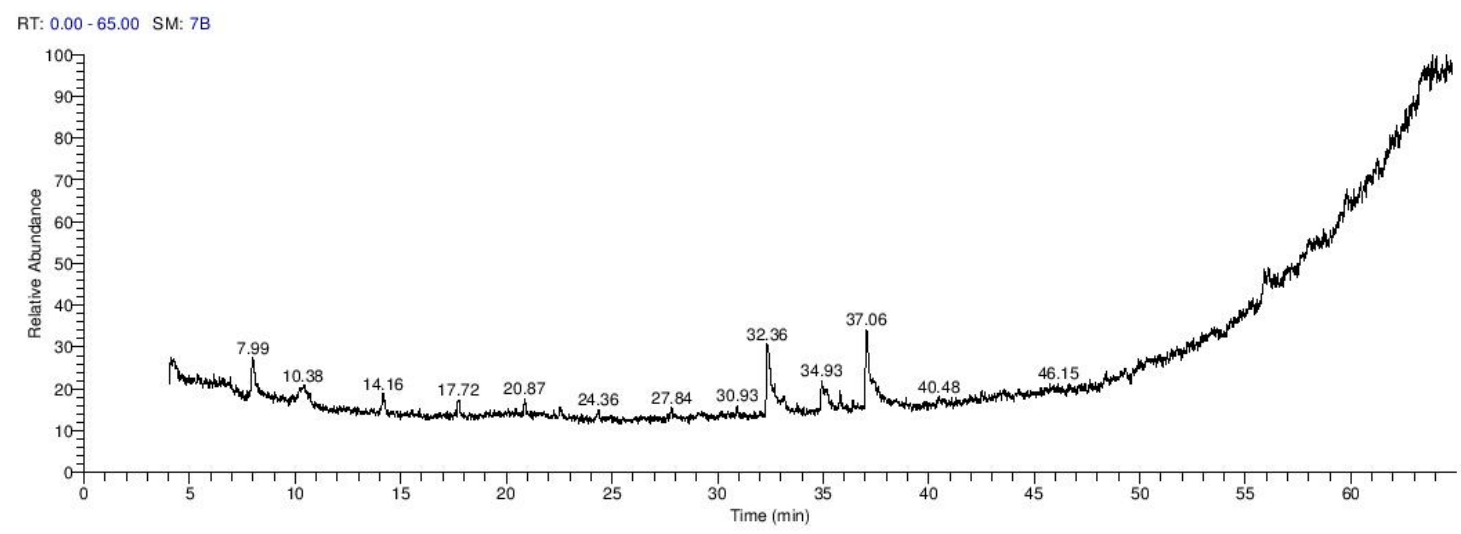

Fig. (3): GC-MS chromatogram of aqueous plant extract of Salvia fruticose 


\section{In vitro study}

The efficacy of in vitro treatment of Origanum majorana, Ziziphus spina-christi and Salvia fruticosa aqueous extracts was studied on adult snails of Biomphalaria alexandrina and Bulinus truncatus as well as on miracidia and cercariae in both Egyptian species of Schistosoma mansoni and Schistosoma haematobium at different concentrations. The effect of all aqueous extracts on adult snails, miracidia and cercariae were effective, and this mainly depends on incubation time and concentration.

\section{Molluscicide activity}

Untreated snails were moved inside the container with their feet extended outside the shell. When mechanical stimulation was applied with a sharp tool to the foot sole, they immediately retracted to their shell. The toxic effects of active plant extracts are shown on tested snails as follows. In the partially dead snails, partially dead snails there was a partial regression (withdrawal response), but in dead snails, there was no retraction at all to the mechanical stimulation of the foot sole with a sharp needle. Also, the high doses of the active extracts caused a clear swelling of a cephalopodal mass and the emergence of hemorrhagic "blisters" on the ventral surface of the foot sole and its failure to respond to mechanical stimulation with a sharp needle. Mucous secretion was also observed in the foot.

From Table (4) $\mathrm{LC}_{50}$ and $\mathrm{LC}_{90}$ of the leaf extracts of Origanum majorana, Ziziphus spinachristi and Salvia fruticosa were calculated. The current data revealed that the aqueous extract of Origanum majorana leaves have been demonstrated the highest molluscicidal activity in the two tested snails as $\left(\mathrm{LC}_{50}=42 \mathrm{mg} / \mathrm{ml}\right.$ and $\mathrm{LC}_{90}=172 \mathrm{mg} / \mathrm{ml}$ on B. alexandrina, and $\mathrm{LC}_{50}=35 \mathrm{mg} / \mathrm{ml}$ and $\mathrm{LC}_{90}=140 \mathrm{mg} / \mathrm{ml}$ on $B$. truncates $)$ followed by Ziziphus spina-christi as $\left(\mathrm{LC}_{50}=43 \mathrm{mg} / \mathrm{ml}\right.$ and $\mathrm{LC}_{90}=374 \mathrm{mg} / \mathrm{ml}$ on $B$. alexandrina, $\mathrm{LC}_{50}=35 \mathrm{mg} / \mathrm{ml}$ and $\mathrm{LC}_{90}=299 \mathrm{mg} / \mathrm{ml}$ on $B$. truncates), while Salvia fruticosa showed molluscicide activity, but it was less than previous as $\left(\mathrm{LC}_{50}=69 \mathrm{mg} / \mathrm{ml}\right.$ and $\mathrm{LC}_{90}=315 \mathrm{mg} / \mathrm{ml}$ on $B$. alexandrina, $\mathrm{LC}_{50}=56 \mathrm{mg} / \mathrm{ml}$ and $\mathrm{LC}_{90}=219$ $\mathrm{mg} / \mathrm{ml}$ on B. truncates). The results showed that the Bulinus truncatus snail was more affected than the Biomphalaria alexandrina, possibly due to the size of the snail. On the other hand, the positive group showed complete death of snails (100\%) after $24 \mathrm{hr}$. of incubation. Conversely, the untreated group was still living until the experiment was ended.

Table (4): Molluscicide activity of Origanum majorana, Ziziphus spina-christi and Salvia fruticosa aqueous extracts against Biomphalaria alexandrina and Bulinus truncates after 24 hours of exposure in vitro

\begin{tabular}{|c|c|c|c|c|c|}
\hline Snails & Plant extract & $\mathrm{LC}_{25}$ & $\mathrm{LC}_{50}$ & $\mathrm{LC}_{75}$ & $\mathrm{LC}_{90}$ \\
\hline \multirow{3}{*}{ 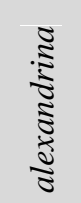 } & Origanum majorana & 14 & 42 & 88 & 172 \\
\hline & Ziziphus spina-christi & 17 & 43 & 111 & 374 \\
\hline & Salvia fruticosa & 28 & 69 & 150 & 315 \\
\hline \multirow{3}{*}{ 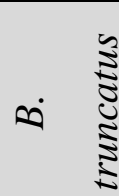 } & Origanum majorana & 11 & 35 & 68 & 140 \\
\hline & Ziziphus spina-christi & 16 & 35 & 87 & 299 \\
\hline & Salvia fruticosa & 24 & 56 & 112 & 219 \\
\hline
\end{tabular}




\section{Miracicidal activity}

The results showed that the mortality rate of miracidia was high in the two Egyptian species of Schistosoma exposed to plant extracts with different concentrations and at time intervals from 15 to 180 min. Origanum majorana was the most active in killing $100 \%$ of miracidia after $30 \mathrm{~min}$ at $\left(\mathrm{LC}_{50}=24 \mathrm{mg} / \mathrm{ml}\right.$ and $\mathrm{LC}_{90}=74 \mathrm{mg} / \mathrm{ml}$ on $S$. mansoni miracidia, at $\mathrm{LC}_{50}=23 \mathrm{mg} / \mathrm{ml}$ and $\mathrm{LC}_{90}=65 \mathrm{mg} / \mathrm{ml}$ on $S$. haematobium miracidia). The effect started at a low concentration of $6.25 \mathrm{mg} / \mathrm{ml}$ at $15 \mathrm{~min}$, and the mortality rate began to gradually rise until reached $100 \%$ at a concentration of $50 \mathrm{mg} / \mathrm{ml}$ at $90 \mathrm{~min}$. The results were the same on miracidia for the two species of schistosomes. As for Ziziphus spina-christi, it also had a fatal effect on miracidia at $\left(\mathrm{LC}_{50}=31 \mathrm{mg} / \mathrm{ml}\right.$ and $\mathrm{LC}_{90}=96 \mathrm{mg} / \mathrm{ml}$ on $S$. mansoni miracidia, at $\mathrm{LC}_{50}=29 \mathrm{mg} / \mathrm{ml}$ and $\mathrm{LC}_{90}=84 \mathrm{mg} / \mathrm{ml}$ on $S$. haematobium miracidia), the effect began to appear in the lowest concentration after $30 \mathrm{~min}$ and the death rate increased to reached $100 \%$ at a concentration of 50 $\mathrm{mg} / \mathrm{ml}$ after $120 \mathrm{~min}$ of exposure to the extract. It had the same effect on miracidia in two species of schistosomes. While, Salvia fruticosa showed a lower effect against miracidia for the two species of schistosomes, than the two other plants at $\left(\mathrm{LC}_{50}=49 \mathrm{mg} / \mathrm{ml}\right.$ and $\mathrm{LC}_{90}=177 \mathrm{mg} / \mathrm{ml}$ on $S$. mansoni miracidia, at $\mathrm{LC}_{50}=34 \mathrm{mg} / \mathrm{ml}$ and $\mathrm{LC}_{90}=164 \mathrm{mg} / \mathrm{ml}$ on $S$. haematobium miracidia), the effect began to appear in the lowest concentration after 30 min and gradually increased until reached to $100 \%$ at a concentration of $100 \mathrm{mg} / \mathrm{ml}$ at $120 \mathrm{~min}$ in Schistosoma mansoni and it reached $100 \%$ at a concentration of 100 at $90 \mathrm{~min}$ in Schistosoma haematobium (Table 5). Whereas, the positive group showed complete death of miracidia (100\%) after 30 min of incubation. On the contrary, the negative group was still living until the experiment was ended.

Table (5): Miracicidal activity of Origanum majorana, Ziziphus spina-christi and Salvia fruticosa aqueous extracts against miracidia after 180 min of exposure under laboratory conditions

\begin{tabular}{|c|c|c|c|c|c|c|c|}
\hline \multicolumn{3}{|c|}{ Miracidia } & Plant extract & $\mathrm{LC}_{25}$ & $\mathrm{LC}_{50}$ & $\mathrm{LC}_{75}$ & $\mathrm{LC}_{90}$ \\
\hline \multirow{3}{*}{\multicolumn{3}{|c|}{ 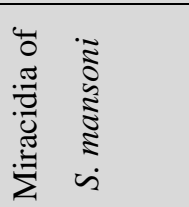 }} & Origanum majorana & 7 & 24 & 39 & 74 \\
\hline & & & Ziziphus spina-christi & 11 & 31 & 49 & 96 \\
\hline & & & Salvia fruticosa & 15 & 49 & 91 & 177 \\
\hline \multirow{3}{*}{ 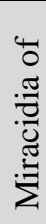 } & \multirow{3}{*}{$\dot{s}$} & \multirow{3}{*}{ 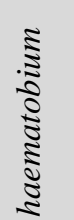 } & Origanum majorana & 5 & 23 & 35 & 65 \\
\hline & & & Ziziphus spina-christi & 8 & 29 & 45 & 84 \\
\hline & & & Salvia fruticosa & 10 & 34 & 73 & 164 \\
\hline
\end{tabular}

\section{Cercaricidal activity}

When cercariae was exposed to different concentrations of plant extracts, the effect began to appear after $15 \mathrm{~min}$ of exposure to the lowest concentration of the two schistosomes species, and the mortality rate increased gradually with the increase in the period of exposure. Origanum majorana was the most active in $100 \%$ mortality of cercariae after $90 \mathrm{~min}$ at $\left(\mathrm{LC}_{50}=17 \mathrm{mg} / \mathrm{ml}\right.$ and $\mathrm{LC}_{90}=66 \mathrm{mg} / \mathrm{ml}$ on $S$. mansoni cercariae, and at $\mathrm{LC}_{50}=16 \mathrm{mg} / \mathrm{ml}$ and $\mathrm{LC}_{90}=54 \mathrm{mg} / \mathrm{ml}$ on $S$. haematobium cercariae). Origanum majorana showed the same effect on cercariae in two species of schistosomes, it started the effect at the lowest concentration after $15 \mathrm{~min}$, and the mortality 
rate began to gradually rise until reached $100 \%$ at a concentration of $50 \mathrm{mg} / \mathrm{ml}$ at $90 \mathrm{~min}$. As for Ziziphus spina-christi, it also had a mortality effect on cercariae at $\left(\mathrm{LC}_{50}=17 \mathrm{mg} / \mathrm{ml}\right.$ and $\mathrm{LC}_{90}=$ $66 \mathrm{mg} / \mathrm{ml}$ on $S$. mansoni cercariae, and at $\mathrm{LC}_{50}=23 \mathrm{mg} / \mathrm{ml}$ and $\mathrm{LC}_{90}=67 \mathrm{mg} / \mathrm{ml}$ on $S$. haematobium cercariae), the mortality began to appear when exposed to a low concentration of $6.25 \mathrm{mg} / \mathrm{ml}$ at $15 \mathrm{~min}$ and the death rate increased to reach $100 \%$ at a concentration $50 \mathrm{mg} / \mathrm{ml}$ after $120 \mathrm{~min}$ of exposure to the extract. It had the same effect on cercariae in two species of schistosomes. Whereas, Salvia fruticosa showed an effect against cercariae for the two Egyptian species of Schistosoma, but it was less than previous at $\left(\mathrm{LC}_{50}=31 \mathrm{mg} / \mathrm{ml}\right.$ and $\mathrm{LC}_{90}=193 \mathrm{mg} / \mathrm{ml}$ on $S$. mansoni cercariae, $\mathrm{LC}_{50}=14 \mathrm{mg} / \mathrm{ml}$ and $\mathrm{LC}_{90}=140 \mathrm{mg} / \mathrm{ml}$ on $S$. haematobium miracidia), The effect began to appear in the lowest concentration after $60 \mathrm{~min}$ and gradually increased until it reached to $100 \%$ at a concentration of $100 \mathrm{mg} / \mathrm{ml}$ at $90 \mathrm{~min}$ in Schistosoma mansoni but the effect started to appear at low concentration of $6.25 \mathrm{mg} / \mathrm{ml}$ at $15 \mathrm{~min}$ and reached to $100 \%$ at a concentration of 50 at $120 \mathrm{~min}$ in Schistosoma haematobium (Table 6). While the treated group showed complete death of cercariae (100\%) after $30 \mathrm{~min}$ of incubation. On the contrary, the untreated group was still living until the experiment was ended.

Table (6): Cercaricidal activity of Origanum majorana, Ziziphus spina-christi and Salvia fruticosa aqueous extracts against cercariae after $180 \mathrm{~min}$ of exposure under laboratory conditions

\begin{tabular}{|c|c|c|c|c|c|}
\hline Cercariae & Plant extract & $\mathrm{LC}_{25}$ & $\mathrm{LC}_{50}$ & $\mathrm{LC}_{75}$ & $\mathrm{LC}_{90}$ \\
\hline \multirow{3}{*}{ 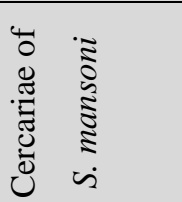 } & Origanum majorana & 9 & 17 & 30 & 66 \\
\hline & Ziziphus spina-christi & 9 & 17 & 30 & 66 \\
\hline & Salvia fruticosa & 8 & 31 & 73 & 193 \\
\hline \multirow{3}{*}{ 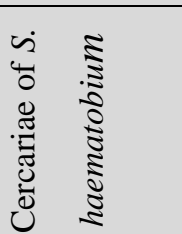 } & Origanum majorana & 1 & 16 & 25 & 54 \\
\hline & Ziziphus spina-christi & 9 & 23 & 33 & 67 \\
\hline & Salvia fruticosa & 6 & 14 & 48 & 140 \\
\hline
\end{tabular}

\section{DISCUSSION}

Schistosomiasis is widespread in sub-Saharan Africa, particularly in poor provincial society, imposing a great social and economic load. Due to the presence of a single drug approved by the World Health Organization, effective strategies for controlling this disease were essential, it is an important approach to intensify control measures to eliminate the aqueous stages, which are snails and miracidia, as well as cercariae in the life cycle of schistosomiasis or at least reduce it. Niclosamide, is the synthetic material used by the World Health Organization to control host aquatic snails, miracidia and cercariae, but it is very expensive, also toxic to nontarget organisms such as fish and the snail resistance is very possible. It is important to research the biological agents that can reduce the shedding of cercariae and kill both miracidia and cercariae. Several researchers have tested some biological control agents as well as biopesticides 
including snail predators, plant extracts, fungi, and bacteria (Younes et al., 2017; Abd El-Ghany et al., 2018).

Due to the diversity in biological activities and molecules that natural products provide, they are a good alternative to conventional or chemical therapeutic compounds. This biological diversity is the result of a large number of as yet unknown active compounds. Despite advances in medicinal chemistry, biotechnology, and genomics, the discovery of new drugs for schistosomiasis treatment remains challenging (Silva et al., 2017; Lago et al., 2018). The aqueous extract of Origanum majorana, Ziziphus spina-christi and Salvia fruticosa was chosen because water is a safe and non-toxic, widespread solvent avoiding high toxicity of the organic solvent (such as methanol, acetone, chloroform and dichloromethane) to live organisms (Kinuthia et al. 2015).

It was observed in this study the continuous movement of the snails and also the aggregate on the water-air interface. Brackenbury (1999) and Adetunji and Salawu (2010) agreed with these results and noticed that when placing bulinid snails with lethal doses of the extract, the snails remain in a constant state of movement to try to get out of the extract, which causes them to have an irritating behavior and also floats on the surface of the water that does not make their body in close and continuous contact with the extract, they try to avoid the extract. In this study the lethal concentrations $\mathrm{LC}_{50}$ of aqueous extracts of Origanum majorana was $42 \mathrm{mg} / \mathrm{ml}$ on $B$. alexandrina and $35 \mathrm{mg} / \mathrm{ml}$ on $B$. truncates, for Ziziphus spina-christi it was $43 \mathrm{mg} / \mathrm{ml}$ on $B$. alexandrina and $35 \mathrm{mg} / \mathrm{ml}$ on $B$. truncates, while for Salvia fruticosa it was $69 \mathrm{mg} / \mathrm{ml}$ on $B$. alexandrina and $56 \mathrm{mg} / \mathrm{ml}$ on $B$. truncates after 24 hours of exposure. Several researchers have examined the effect of medicinal plants as molluscicidal, Kiros et al. (2014) who confirmed that the aqueous extract of Glinus lotoides fruits had an anti-snail activity on Biomphalaria pfeifferi. Whereas, Al-Snafi (2015) confirmed that the Anagallis aryensis extract has strong efficacy as a molluscicide. This activity is due to the presence of two compounds called anagakkoside B and desgluco-anagaloside B, which were found to have similar activity to that of the Niclosamide (synthetic molluscicide). Ibrahim and Ghoname (2018) confirmed that the Anagallis arvensis aqueous extract had a molluscicidal effect against Biomphalaria alexandrina and state that hormonal activity, reproductive rates and reduction in survival were reduce after treatment. Jia et al. (2019) documented that the pentacyclic triterpenoid saponin derived from Camellia oleifera has molluscicidal activity against Oncomelania hupensis, Biomphalaria alexandrina and Bulinus truncatus. Matos et al. (2020) proved that the curcumin extract has molluscicidal activity against Biomphalaria glabrata and stated that the embryo development, egg hatching and fecundity rate of adult snails were decreased.

According to the World Health Organization, the lethal concentration $\left(\mathrm{LC}_{50}\right)$ of any molluscicide should not exceed $100 \mathrm{ppm}$ (WHO, 2019). In the present study, the active extracts caused a clear swelling of a cephalopodal mass, and an emergence of hemorrhagic "blisters" on the ventral surface of the footsole and its failure to respond to the mechanical stimulation with a sharp needle. Mucous secretion was also observed in the foot. Snails exhibited many behavioral responses after exposure to the active plant extracts examined in this study, including the "distress syndrome" which refers to intoxication and which has been described in other species such as the planorbid type by Sullivan and Cheng (1975), Van Aardt and Coertze (1981) and Brackenbury and Appleton (1999). The swelling of the tissues was not limited to the entire cephalopodal mass, but also included the tentacles. According to Brackenbury and Appleton (1999) when the snail is exposed to the lethal concentration of plant extracts, it causes haemorrhae in the cephalopodal mass due to the accumulation of water in the soft body of the 
snail. However, according to that study, an imbalance in the permeability of the foot sole epithelium was seen by preventing its normal osmo-regulatory function and attributing this to the toxic principles of the active plant extracts Brackenbury and Appleton (1999). However, upon starting the recovery period by transferring the snail into water-free of plant extracts, the toxic effect of sublethal doses of plant extracts was reversible. This observation was recorded in several results, including Harry and Aldrich (1963), and Van Aardt and Coertze (1981) said after exposure to copper sulphate the snails (Bulinus tropica) can move again in sublethal dose.

Phytochemical analysis showed the presence of many active substances such as Cedren, Phenol, Butanone, Eudesmol, Propanol, Capsaicin, Guanosine, Glycine Thienopyridine, Spathulenol, Purinol, Spirosten. According to Mandefro's result (2017) the chemical analysis of the plants he used contained many active substances such as saponins and carbohydrates, but he confirmed that the main snails killing compounds in the aqueous extract of this plant is saponins. Several other studies have also documented that saponins are a highly effective molluscicide. Mandefro explained that the saponin causes damage to the animal cell membrane by forming a complex compound with the plasma and the membrane.

The infectivity of both species of schistosomes (Schistosoma mansoni and Schistosoma haematobium) miracidia were greatly reduced by Origanum majorana, Ziziphus spina-christi and Salvia fruticosa. This may be explained as the $\mathrm{LC}_{50}$ of plant extracts of the three tested plants had weakened the ability of the miracidia to penetrate the soft tissues of the snails. Several studies have investigated the effect of plant extracts on miracidia, Bakry et al. (2002) they observed that when Schistosoma mansoni miracidia were exposed to $\mathrm{LC}_{25}$ extract of methanol from Euphorbia lacteal, it reduced the ability of miracidia to infect the intermediate host Biomphalaria alexandrina snails. El-Emam et al. (1986) reported that the infection rate was reduced when treated with $50 \mathrm{ppm}$ from Calendula micrantha extract. There are also many studies with the same result, including Tantawi et al. (2000) who studied the extract from Solanium dudium, Sharaf El-Din et al. (2001) studied the extract from Zygophyllum simplex, Bakry et al. (2004) obtained the extracts from Agave franzosinii and methanol extracts from Furcraea selloea and Ophioglossum reticulatum. Also, these results were consistent with several investigations using a chemical compound or plant extract as a molluscicides such as Rawi et al. (1995) investigated the extracts from Ammi majus and Calendula micrantha officinalis against Bulinus truncatus and Biomphalaria alexandrina, Mohamed et al. (2000) studied the effect of Abamectin on Biomphalaria alexandrina, Abdel Aziz et al. (2011) observations of the effect of methanolic extract of Plectranthus tenuiflorus revealed similar conclusions. Thus, Ansari et al. (2000) observed that the effect of Artemisia maritima caused a significant decrease in cercarial shedding and cercarial production in Biomphalaria alexandrina the intermediate host of S. mansoni. Sharaf El-Din et al. (2001) treated Biomphalaria alexandrina with sublethal concentrations of aqueous extraction of Zygophyllum simplex, he obtained similar reduction in cercarial shedding and cercarial production. Shortening in cercarial shedding period may be due to the effect of the extract on the soft tissues of the snails, as well as the penetration of the miracidia into the tissues of the snails. This leads to a disturbance in the physiological functions of the treated snail body, which leads to a shorter period of shedding as well as the life span (Bakry et al., 2017).

When the miracidia attacks the snail, and stabilizes in the soft tissues of it, it undergoes asexual reproduction to produce cercariae, the infectious stage of schistosomiasis. According to previous investigations, a single miracidia may be divided to give more than 20000 cercariae (Grimes et al., 2015). The present study showed that the aqueous extract of the tested plants had a 
cercariacidal activity against $S$. mansoni and $S$. haematobium cercariae, where the activity was dependent on both time and dose. This observation is similar to that of Rug and Ruppel (2000) who examined the toxic activity of aqueous and methanol extract of Jatropha curcas and found that the aqueous extract had cercaridcidal activity at 100 ppm killed $100 \%$ of the cercariae after 2 $\mathrm{h}$ and was more efficient than the methanol extract, whereas Mohamed et al. (2005) tested the Nigella sativa seeds on three stages of $S$. mansoni, the result indicates its strong biocidal effects against miracidia, cercariae, and adult worms, Medina et al. (2009) who demonstrated the kaurenoic acid derived from Croton floribundus has cercaricidal activity on cercariae of $S$. mansoni when exposed to $100 \mu \mathrm{g} / \mathrm{mL}^{-1}$, after one hour the mortality rate was $100 \%$, also Chen et al. (2012) who reported the curcumin had high activity against $S$. japonicum cercariae, at a concentration of $8 \mu \mathrm{g} / \mathrm{mL}^{-1}$, after 30 minutes the mortality rate was $100 \%$. Kiros et al. (2014) observed the aqueous extract of Glinus lotoides has cercariacidal activity after $2 \mathrm{~h}$ of exposure at $\mathrm{LC}_{50}$ and $\mathrm{LC}_{90}$ values were 18.7 and $41.7 \mathrm{mg} / \mathrm{l}$, respectively.

\section{Conclusion}

By studying the effect of Origanum majorana, Ziziphus spina-christi and Salvia fruticosa on the intermediate host of Schistosoma mansoni and Schistosoma haematobium, as well as on different life stages. Origanum majorana, Ziziphus spina-christi had strong molluscicidal, miracicidal and cercaricidal activity for both Egyptian species schistosomes in vitro, while Salvia fruticosa was less effective than the previous ones. This requires more studies to know the active substances that had this fatal effect on snails, miracidia, and cercariae.

\section{REFERENCES}

AAT Bioquest Inc. (2018). Quest Graph, LC50 Calculator. https://www.aatbio.com/tools/lc50calculator.

Abd El-Ghany, A.M.; Salama, A.; Abd El-Ghany, N.M. and Gharieb, R.M.A (2018): New approach for controlling snail host of Schistosoma mansoni, Biomphalaria alexandrina with cyanobacterial strains-derived C-Phycocyanin. Vector Borne Zoonotic Dis., 18 (9): 464-468.

Abdel Aziz, I.Z.; El-badry, A.A. and El-Gayed, S.H. (2011). In vitro anti-schistosomal activity of "Plectranthus teniflorus" on miracidium, cercariae snd schistosomula stage of Schitosoma mansoni. Res. J. Parasitol., 6 (2): 74-82.

Adetunji, V.O. and Salawu, O.T. (2010). Efficacy of ethanolic leaf extracts of Carica papaya and Terminalia catappa as molluscicides against the snail intermediate hosts of schistosomiasis. J. Med. Plants Res., 4: 2348-2352.

Al-Harbi, N.O. (2011). Effect of marjoram extract treatment on the cytological and biochemical changes induced by cyclophosphamide in mice. J. Med. Plants Res., 5 (23): 5479-5485.

Al-Sarar, A.; Hussein, H.; Abobakr, Y. and Bayoumi, A. (2012). Molluscicidal activity of methomyl and cardenolide extracts from Calotropis procera and Adenium arabicum against the land snail Monacha cantiana. Molecules, 17: 5310-5318. 
Al-Snafi, A.E. (2015). The chemical contents and pharmacological effects of Anagallis arvensisA review. Int. J. Pharm., 5: 37-41.

Amin, A. and Mahmoud-Ghoneim, D. (2009). Zizyphus spina-christi protects against carbon tetrachloride-induced liver fibrosis in rats. Food Chem. Toxicol., 47: 2111-2119.

Ansari, M.A.; Vasudevan, P.; Tandon, M. and Razdan, R.K. (2000). Larvicidal and mosquito repellent action of peppermint (Mentha piperata) oil. Bioresour. Technol., 71: 267-271.

Anyan, W.K.; Abonie, S.D; Aboagye-Antwi, F.; Tettey, M.D.; Nartey, L.K.; Hanington, P.C.; Anang, A.K. and Muench, S.B. (2019). Concurrent Schistosoma mansoni and Schistosoma haematobium infections in a Peri-Urban community along the Weija Dam in Ghana: A wake up call for effective National Control Programme. Acta Trop, 199: 105116.

Bakry, F.A and Hamdi, S.A.H. (2007). Molluscicidal activity of latex Aqueous solution of Euphorbia acetonitril and Euphorbia granulate against the intermediate hosts of Schistosomiasis and Fascioliasis. J. Union. Arab. Biol. 27: 101-126.

Bakry, F.A.; Ismail, S.M. and Abd El-Atti, M.S. (2015). Glyphosate herbicide induces genotoxic effect and physiological disturbances in Bulinus truncatus snails. Pest. Biochem. Physiol., 123: $24-30$.

Bakry, F.A.; Eleiwa, E.M.; Taha, S.A. and Ismil, S.M. (2016). Comparative toxicity of paraquat herbicide and some plant extracts in Lymnaea natalensis snails. Toxicol. Indust. Health, 32: 143-153.

Bakry, F.A.; Ismail, S.M. and Abd El- Monem, S. (2004). Effect of two plant extracts on some biological and enzymatic activities of Bulinus truncatus with Schistosoma haematobium. J. Aqual. Biol. Fish, 8 (4): 313-446.

Bakry, F.A. (2009). Impact of some plant extracts on histological structure and protein patterns of Biomphalaria alexandrina snails. Globul. J. Molecul. Sci., 4 (1): 34-41.

Bakry, F.A.; El-Garhy, M.; Abd El-Atti, M. and Atwa, M.Th. (2017). Effects of the extracts of Euphorbia pulcherima and Atriplex nummularia on the infectivity of Schistosoma haematobium to Bulinus truncatus snails. Adv. Biomech., 1 (2): 34-41

Bakry, F.A; Ragab, F.M.A and Sakran, A.M.A. (2002). Effect of some plant extracts with molluscicidal properties on some biological and physiological parameters of Biomphalaria alexandrina snails. J. Ger. Soc. Zool., 38: 101-111.

Brackenbury, T.D. and Appleton, C.C. (1999). Structural damage to the foot-sole epithelium of Bulinus africanus following exposure to a plant molluscicide. Malacologia, 41 (2): 393-401.

Brackenbury, T.D. (1999). Gross histopathological effects of an extract of Agave attenuate on the epithelium of the digestive tract of Bulinus africanus. Ann. Trop. Med. Parasitol., 93: 519526.

Chen, Y.Q.; Xu, Q.M.; Li, X.R.; Yang, S.L. and Zhu-Ge, H.X. (2012). In vitro evaluation of schistosomicidal potential of curcumin against Schistosoma japonicum. J. Asian Nat. Prod. Res., 14: 1064-1072. 
Deshmane, D.N.; Gadgoli, C.H. and Halade, G.V. (2007). Anticonvulsant effect of Origanum majorana L., Pharmacologyonline, 1: 64-78.

Duletić-Laušević, S.; Alimpić Aradski, A.; Šavikin, K.; Knežević, A.; Milutinović, M.; Stević, T.; Vukojević, J.; Marković, S.; Marin, P.D. (2018). Composition and biological activities of Libyan Salvia fruticosa Mill. and S. lanigera Poir. extracts. S. Afr. J. Bot., 117: 101-109.

Ekpo, M.A. and Etim, P.C. (2009). Antimicrobial activity of ethanolic and aqueous extracts of Sida acuta on microorganisms from skin infections. J. Med. Plants Res., 3: 621-624.

El-Bolkiny, Y.E.; Salem, M.L.; Attia, W.Y. and Al-sharkawi, I.M. (1997). Toxicological study of Ammi majus as a plant molluscicide on the hemolytic. J. Egypt. Grt. Soc. Zool., 23 (A): 379401.

El-Emam, M.A.; Shoeb, H.A.; Ebid, F.A. and Refai, L.A. (1986). Snail control by Calendula micrantha officinalis. J. Egypt. Soc. Parasitol., 16 (2): 563-571.

El-Sayed, M.M.; Abdel-Hameed, E.S.; El-Nahas, H.A. and El-Wakil, E.A. (2006). Isolation and identification of some steroidal glycosides of Furcraea selloa. Pharmazie, 61 (5): 478-482.

Fraihat, A.; Alatrash, L.; Abbasi, R.; Abu-Irmaileh, B.; Hamed, S.; Mohammad, M.; Abu-Rish, E. and Bustanji, Y. (2018). Inhibitory effects of methanol extracts of selected plants on proliferation two human melanoma cell lines. Trop. J. Pharm. Res., 17: 1645-1650.

Grimes, J.E.; Croll, D.; Harrison, W.E.; Utzinger, J.; Freeman, M.C. and Templeton, M.R. (2015). The roles of water, sanitation and hygiene in reducing schistosomiasis: a review. Parasite and Vectors, 8: 156.

Guo, W.; Zheng, L.Y.; Wu, Y.Q. and Fan, X.L. (2008). Synthesis and cercaricidal activities of a serial of novel self-diffused cercaricides derived from niphensamide. Chin. Chem. Lett., 19: 406-408.

Guo, W.; Zheng, L.Y.; Li, Y.D.; Wu, R.M.; Chen, Q.; Yang, D.Q. and Fan, X.L. (2016). Discovery of molluscicidal and cercaricidal activities of 3-substituted quinazolinone derivatives by a scaffold hopping approach using a pseudo-ring based on the intramolecular hydrogen bond formation. Eur. J. Med. Chem., 10 (115): 291-294.

Harry, H.W. and Aldrich, D.V. (1963). The distress reaction to toxic concentrations of inorganic ions. Malacologia, 1: 283-287.

Ibrahim, A.M. and Ghoname, S.I. (2018). Molluscicidal impacts of Anagallis arvensis aqueous extract on biological, hormonal, histological and molecular aspects of Biomphalaria alexandrina snails. Exp. Parasitol. 192: 36-41.

Ibrahim, A.M. and Abdalla, A.M. (2017). Impact of Moringa oleifera seed aqueous extract on some biological, biochemical, and histological aspects of Biomphalaria alexandrina snails. Environ. Sci. Pollut.n Res., 24: 28072-28078.

Janicsák, G.; Máthé, I.; Miklóssy-Vári, V. and Blunden, G. (1999). Comparative studies of the rosmarinic and caffeic acid contents of Lamiaceae species. Biochem. Syst. Ecol., 27: 733-738.

Jia, T.W.; Wang, W.; Sun, L.P.; Lv, S.; Yang, K.; Zhang, N.M.; Huang, X.B.; Liu, J.B.; Liu, H.C.; Liu, R.H.; Gawish, F.A.; Habib, M.R.; El-Emam, M.A.; King, C.K. and Zhou, X.N. (2019). Molluscicidal effectiveness of Luo-Wei, a novel plant-derived molluscicide, against 
Oncomelania hupensis, Biomphalaria alexandrina and Bulinus truncatus. Infect. Dis. Poverty, 8 (1): 27.

Kadioglu, O.; Jacob, S.; Bohnert, S.; Na̧ㅡ, J.; Saeed, M.E.M.; Khalid, H.; Merfort, I.; Thines, E.; Pommerening, T. and Efferth, T. (2016). Evaluating ancient Egyptian prescriptions today: anti-inflammatory activity of Ziziphus spina-christi. Phytomedicine, 23 (3): 293-306.

Kenawy, E.-R. and Rizk, E.-S. (2004). Polymeric controlled release formulations of niclosamide for control of Biomphalaria Alexandrina, the vector snail of schistosomiasis. Macromol. Biosci., 4: 119-128.

King, C.H. and Dangerfield-Cha, M. (2008). The unacknowledged impact of chronic schistosomiasis. Chronic Illness, 4 (1): 65-79.

Kinuthia, K.G.; Anjili, O.C.; Kabiru, W.E.; Kigondu, M.E.; Ingonga, M.J. and Gikonyo, K.N. (2015). Toxicity and efficacy of aqueous crude extracts from Allium sativum, Callistemon citrinus and Moringa stenopetala against L. major. Kabarak J. Res. Inno., 3: 9-20.

Kiros, G.; Erko, B.; Giday, M. and Mekonnen, Y. (2014). Laboratory assessment of molluscicidal and cercariacidal effects of Glinus lotoides fruits. BMC Res. Notes, 7: 220.

Kjetland, E.F.; Ndhlovu, P.D.; Gomo, E.; Mduluza, T.; Midzi, N.; Gwanzura, L.; Mason, P.R.; Sandvik, L.; Friis, H.; and Gundersen, S.G. (2006). Association between genital schistosomiasis and HIV in rural Zimbabwean women. AIDS, 20 (4): 593-600.

Koutsoulas, A.; Čarnecká, m.; Slanina, J.; Tóth, J. and Slaninová, I. (2019). Characterization of phenolic compounds and antiproliferative effects of Salvia pomifera and Salvia fruticosa extracts. Molecules, 24: 2921.

Kozłowska, M.; Laudy, A.E.; Starosciak, B.J.; Napiorkowski, A. Chomicz, L. and Kazimierczuk, Z. (2010). Antimicrobial and antiprotozoal effect of sweet marjoram (Origanum majorana L.). Acta Sci. Pol., Hortorum Cultus. 9 (4): 133-141.

Lago, E.M.; Xavier, R.P.; Teixeira, T.R.; Silva, L.M.; da Silva Filho, A.A. and de Moraes, J. (2018). Antischistosomal agents: State of art and perspectives. Future Med. Chem., 10: 89120.

Leitchfield, J.T. and Wilcoxon, F. (1949). A simplified method of evaluating dose-effect experiment. J. Pharmacol. Exp. Therapeut. 96: 99-113.

Lemma, A. (1970). Laboratory and field evaluation of the molluscicidal properties Phytolacca dodecandra (Endod). Bull. World Health Organization, 42: 597-612.

Leung, Y. and Foster, S. (1996). Encyclopaedia of common natural ingredients used in food, drugs and cosmetics, John Wiley and Sons, Inc, Press, Netherlands, 364-366.

Li, Y.; Xie, Y.; Liu, C.; Guo, W.; Li, X.; Li, X.; Zeng, Q. and Fan, X. (2013). Nano-film pesticide for Schistosoma japonicum cercariae: synthesis, characterization, toxicity and insecticidal effect. RSC Adv., 3: 19956-19960.

Mandefro, B.; Mereta, S.T.; Tariku, Y. and Ambelu, A. (2017): Molluscicidal effect of Achyranthes aspera L. (Amaranthaceae) aqueous extract on adult snails of Biomphalaria pfeifferi and Lymnaea natalensis. Infec. Dis. Poverty, 6: 133. 
Martha, R. and Gutierrez, P. (2012). Inhibition of advanced glycation end-product formation by Origanum majorana, in vitro and in streptozotocin-induced diabetic rats. J. Evid. Based Complement Altern. Med., 1: 1-8.

Martins, M.C.; Silva, M.C.; Silva, L.R.; Lima, V.L.; Pereira, E.C.; Falcáo, E.P.; Melo, A.M.; de Silva, N.H. (2014). Usnic acid potassium salt: an alternative for the control of Biomphalaria glabrata (Say, 1818). PLoS One, 9: e111102.

Matos, J.L.; da Silva, K.R.; Paula, L.A.; Cunha, W.R.; Ramos, S.B.; Rodrigues, V.; Cabrald, F.J. and Magalhães, L.G. (2020). Molluscicidal and cercaricidal activities of curcumin on Biomphalaria glabrata and Schistosoma mansoni cercariae. Pest Manag. Sci., 76: 1228-1234.

Medina, J.M.; Peixoto, J.L.B.; Silva, A.A.; Haraguchi, S.K.; Falavigna, D.L.M.; Zamuner, M.L.M.; Sarragiotto, M.H. and Vidotti, G.J. (2009). Evaluation of themolluscicidal and Schistosoma mansoni cercariae activity of Croton floribundus extracts and kaurenoic acid. Brazilian J. Pharmacogn., 19: 207-211.

Michel, C.G.; Nesseem, D.I. and Ismail, M.F. (2011). Anti-diabetic activity and stability study of the formulated leaf extract of Zizyphus spinachristi (L.) wild with the influence of seasonal variation. J. Ethnopharmacol., 133: 53-62.

Mohamed, A.Z.; Metwally, N.M. and Mahmoud, S.S. (2005). Sativa seeds against Schistosoma mansoni different stages. Mem. Inst. Oswaldo Cruz, 100: 205-211.

Mohamed, N.; Yasmen, S.H. and Nohir, G. (2011). Antimicrobial activity of water and ethanol Marjoram (Origanum marjorana L.) extract. The 6th Arab and 3rd International Annual Scientific Conference, 2350-2366.

Mohamed, A.M.; Bakry, F.A. and Heiba, F.N. (2000). Molluscicidal effects of abamectin on Biomphalaria alexandrina and its inflection with Schistosoma mansoni. J. $1^{\text {st }}$ Inter. Cong. Biolg. Sci., 1 (2): 207-216.

Mosmann, T. (1983). Rapid colorimetric assay for cellular growth and survival: application to proliferation and cytotoxicity assays. J. Immunol. Methods, 65: 55-63.

Mubaraki, M.A.; Hafiz, T.A.; Al-Quraishy, S. and Dkhil, M.A. (2017). Oxidative stress and genes regulation of cerebral malaria upon Zizyphus spina-christi treatment in a murine model. Microb. Pathog., 107: 69-74.

Nakatani, N. (2000). Phenolic antioxidants from herbs and spices. Bio Factors, 13: 141-146.

Ndassi, V.D.; Anchang-Kimbi, J.K.; Sumbele, I.U.N.; Wepnje, G.B. and Kimbi, H.K. (2019). Prevalence and risk factors associated with $S$. haematobium egg excretion during the dry season, six months following mass distribution of praziquantel (PZQ) in 2017 in the Bafia health area, south west region, Cameroon: A cross-sectional study. J. Parasitol. Res., Article ID 4397263.

Obare, B.A.; Yole, D.; Nonoh, J. and Lwande, W. (2016). Evaluation of cercaricidal and miracicidal activity of selected plant extracts against larval stages of Schistosoma mansoni. J. Natural Sci. Res., 6: 22.

Perrett, S. and Whitfield, P.J. (1996). In vitro cercaricidal activity of schistosomiasis. J. Parasitol., 52: 617. 
Rader, J.I.; Delmonte, P. and Trucksess, M.W. (2007). Recent studies on selected botanical dietary supplement ingredients. Anal. Bioanal. Chem., 389: 27-35.

Raina, A.P. and Negi, K.S. (2012). Essential oil composition of Origanum majorana and Origanum vulgare spp. Hirtum growing in India. Chem. Nat. Comp., 47: 6.

Rawi, S.M.; El-Gindy, H.; Haggag, A.M.; Abou El Hassan, A. and Abdel Kader, A. (1995). Few possible molluscicides from calendula Micrantha officinalis and Ammimajus plants. I. Physiological effect on B. alexandrina and B. truncatus. J. Egypt. Ger. Soc. Zool., 16: 69-75.

Ribeiro, K.A.; de Carvalho, C.M.; Molina, M.T.; Lima, E.P.; López-Montero, E.; Reys, J.R.; de Oliveria, M.B.F.; Pinto, A.V.; Santana, A.E.G. and Goulart, M.O.F. (2009). Activities of naphthoquinones against Aedes aegypti (Linnaeus, 1762) (Diptera: Culicidae), vector of dengue and Biomphalaria glabrata (Say, 1818), intermediate host of Schistosomamansoni. Acta Trop, 111: 44-50.

Rug, M. and Ruppel, A. (2000). Toxic activities of the plant Jatropha curcas against intermediate snail hosts and larvae of schistosomes. Trop. Med. Int. Health, 5: 423-430.

Saathoff, E.; Olsen, A.; Kvalsvig, J.D. and Appleton, C.C. (2004). Patterns of geohelminth infection, impact of albendazole treatment and re-infection after treatment in schoolchildren from rural KwaZulu-Natal/South-Africa. BMC Infect. Dis., 4: 40.

Sachs, J.D. (2001). A new global commitment to disease control in Africa. Nat. Med., 7: 521523.

Sakran, A.M.A. and Bakry, F.A. (2005). Biological and physiological studies on Biomphalaria alexandrina snails exposed to different plant molluscicides. J. Egypt. Ger. Soc. Zool., (48A): 237-256.

Sakran, A.M.A. (2004). Biological and physiological studies on Biomphalaria alexandrina snails exposed to two herbicides. Egypt. J. Zool., 42: 205-215.

Sharaf El-Din, A.T. and El-Sayed, K.A. (2001). Alteration in glucose, glycogen and lipid content in Biomophalaria alexandrina snails post-exposure to Schistosoma mansoni and Echinostoma liei miracidia. J. Egy. Ger. Soc. Zool., 36 (D): 103-113.

Sharma, N.; Dubey, N.K. and Sharma, K. (2011). Screening of insecticidal and antifungal activity of Origanum majorana oil against Callosobruchus chinensis L. and Aspergillus spp. Res. J. Agric. Biol. Sci., 7 (2): 223-227.

Silva, M.P.; de Oliveira, R.N.; Mengarda, A.C.; Roquini, D.B.; Allegretti, S.M.; Salvadori, M.C.; Teixeira, F.S.; de Sousa, D.P.; Pinto, P.L.S.; da Silva Filho, A.A. and de Moraes, J. (2017). Antiparasitic activity of nerolidol in a mouse model of schistosomiasis. Int. J. Antimicrob. Agents, 50: 467-472.

Smithers, S.R. and Terry, R.J. (1965). The infection of laboratory hosts with the cercariae of Schistosoma mansoni and the recovery of adults worms. Parasitol., 55: 695-700.

Sullivan J.T. and Cheng, T.C. (1975). Heavy metal toxicity to Biomphalaria glabrata (Mollusca: Pulmonata). Ann. N. Y. Acad. Sci. 266: 437-444. 
Tantawy, A.A.; Sharaf El-Din, A.T. and Bakry, F.A. (2000). Molluscicidal effect of Solanum dubium (Solanaceae) against Biomphalaria alexandrina snails under laboratory conditions. Proc. Int. Conf. Biol. Sci., 1 (2): 307-318.

Vagi, E.; Rapvi, E.; Hadolin, M.; Vasarhelyine Perdei, K. Balazs, A.; Blazovics, A. and Simandi, B. (2005). Phenolic and triterpenoid antioxidants from Origanum majorana L., herb and extracts obtained with different solvents. J. Agric. Food Chem., 53: 17-21.

Van Aardt, W.J. and Coertze, D.J. (1981). Influence of copper sulphate on the water and electrolyte balance of the fresh water snail Bulinus tropicus. South Afr. J. Zool., 16: 193-199.

Vasudeva, N.; Singla, P.; Das, S. and Sharma, S.K. (2014). Antigout and antioxidant activity of stem and root of Origanum majorana Linn. Am. J. Drug Discov. Dev., 4 (2): 102-112.

WHO, World Health Organization (2011) World health report on Schistosomiasis.

WHO, World Health Organization, (2016). Prevention and control of schistosomiasis and soiltransmitted helminthiasis. Report of a WHO Expert Committee. WHO Technical Report Series Geneva,No. 912.

WHO, World Health Organization (2019), Scientific Working Group on Plant Molluscicide. Available https://apps.who.int/iris/handle/10665/60086 [05 May 2019].

Younes, A.; El-Sherief, H.; Gawish, F. and Mahmoud, M. (2017). Biological control of snail hosts transmitting schistosomiasis by the water bug, Sphaerodema urinator. Parasitol Res., 116: $1257-1264$.

Youssef, A.A. (2010). Studies on the impact of some pesticides and Egyptian plants on some biological and physiological parameters of Biomphalaria alexandrina snails and their susceptibility to infection with Schistosoma mansoni miracidia. M. Sc. Thesis, Faculty of Sci., Al-Azhar Uni., Egypt. 